\title{
The Role of Out-of-School Education in Empowerment of Rural Adults in Etche Ethnic Nationality for Community Development
}

\author{
Dr. J. C. Ihejirika \\ University of Port Harcourt, Choba, Port Harcourt, Nigeria \\ E-mail: ihejirikajohn@yahoo.com
}

Accepted: February 25, 2012 Published: April 14, 2012

Doi:10.5296/ijld.v2i2.1630ＵRL: http://dx.doi.org/10.5296/ijld.v2i2.1630

\begin{abstract}
The purpose of this paper is to examine the roles out-of-school education can play to enhance empowerment of different segments of rural adults in Etche ethnic nationality for community development. The educational history of Etche ethnic nationality reveals a disproportionate emphasis on formal/liberal education at the expense of out-of-school education, the resultant effect of which has been over production of school leavers without practical skills. Consequently, unemployment and poverty manifestations are high and relate to low levels of literacy and lack of vocational skills among the adults and youths. As a matter of fact, this situation demands intervention of out-of-school education which is capable of providing unlimited education opportunities for mobilizing the capacities of various sub-groups of people in Etche ethnic nationality towards rapid transformation of the communities. Based on literature account, this paper submits that out-of-school education has crucial roles to play, whether in providing literacy skills to those who were deprived of formal schooling; or in continuing the education of already literate persons; or still, in providing life and vocational skills to enable rural adults live improved life which can translate to community development. In conclusion, the paper calls for establishment of out-of-school/non-formal education development schemes by Etche and Omuma Local Government Councils to perform for out-of-school education what zonal Schools Board and Ministry of Education do for formal school in Etche ethnic nationality.
\end{abstract}

\section{Introduction}

Nigeria has for long regarded the formal education system as an instrument "par excellence" for effecting national development (NPC, 2004), with less emphasis on out-of-school education which is capable of providing unlimited education opportunities for mobilizing the capacities of various sub-groups towards rapid transformation of societies. This 
disproportionate emphasis on formal education system that is very restrictive and void of opportunities for acquisition of practical skills, to a large extent, occasioned the disparity in level of development existing between urban and rural communities in Etche in particular and Nigeria in general (Ihejirika, 2007).

Etche ethnic nationality which comprises Omuma and Etche Local Government Areas, has witnessed no government approved out-of-school education programme apart from the defunct school-to-land agricultural project at Egbeke Nwuba. Of course, we learnt from Samlowski (2011) that in most countries, formal technical and vocational training is neglected and most times deficient. It could be argued that in the absence of technical and vocational training centres meant for capacity building of rural adults and youths in Etche ethnic nationality, the people are given partial or one sided education. This situation attracted the comment of Tugbiyele (1971) that:

Just as a person will find it difficult to walk on one leg, so will education without either of its two legs: formal and out-of-school education, experience difficulties in performing the functions normally expected of it (p. 55).

This quotation points to the fact that education in Etche ethnic nationality has been limping on one leg (formal education) hence it has not performed all the functions expected of it. The result is that the rural adults and youths lack practical skills in economic, technical and entrepreneurial activities which out-of-school education has the monopoly.

Etche ethnic nationality lies at the north-east of Rivers State towards the southern portions of Imo and Abia States, all in Nigeria, and occupies a land mass of 3,600 square kilometers with an indigenous population of about 1.5 million. It has three main rivers namely: Imo, Oguechie and Otamiriochie all flowing southwards and emptying into the Atlantic ocean. These rivers and their tributaries traverse the large plains of Etche ethnic nationality and render the soil fertile for agriculture; hence the main occupation of the people is farming. The people's produce include food crops such as yam, cassava, cocoyam, plantain, maize, melon, vegetables and fruits. However, lack of modern knowledge of farming has perpetually kept production low and the people poor. In fact, according to Amirize (2002) most families live from hand-to-mouth because they practice an economy that uses local technology, little specialization, limited exchange and subsistence production. Worst still, the women practice the same type of occupation (production of garri from cassava tubers) year in and year out thereby pass the cruel legacy of poverty from parents to children. Other subsidiary occupations of the people are hunting, fishing, petty trading, goat and sheep rearing; all for local markets.

Great hope is attached to the development of the mining sector. Etche is very rich in oil and gas deposits, though this sector is capital-intensive and can only generate a limited number of non-technical jobs and is unlikely to bring relief to the poor and vulnerable population. The fact remains that rural areas in Etche ethnic nationality have for long been suffering from shortage of portable water, electricity, medical care, and jobs, criminality, insecurity and Nigerian government's inability to extend rule of law to all nooks and crannies of the country.

This low level of socio-economic activities among rural adults in Etche ethnic nationality deserve some positive actions hence, this paper is aimed at analyzing the roles out-of-school 
education, with its plethora of programmes, can play to empower them for sustainable community development.

\section{Conceptual Clarifications}

The definitions presented here are required right from the start to make our discussion intelligible by clearly identifying the basic issues to be examined. The title of this paper suggests that the major concepts to be clarified are out-of-school education, empowerment, and community development.

\section{Out-of-school education}

As the name implies, out-of-school education is any form of organized educational activity carried on outside the framework of the formal system to provide selected types of learning to particular sub-groups in the population of adults as well as children. According to Ihejirika (2003), out-of-school education, popularly referred to as non-formal education, is concerned with identifying specific groups of people in the society such as illiterates, farmers, community leaders, rural dwellers, unemployed youths etc; diagnosing their specific problems or needs and seeking the most appropriate means to cater for them to enable them play their various roles in the society. With reference to its content and scope, Tugbiyele (1971) postulated that out-of-school education includes out-of-classroom youth education for school children and university students, literacy education, remedial education for dropouts, technical and vocational training, extension services, health education, community development and continuing education at all levels and for various categories of people including top executives in government, industry and labour, etc. However, he regretted that out-of-school education is a neglected aspect of education which is often looked down upon, hence when given, it is done on an ad hoc basis.

Different attempts have been made by various authors to define out-of-school education. Their definitions have different dimensions but a comprehensive view of the concept came from Bown and Okedara (1981) who stated thus:

The rubric of-out-school education covers training and instruction outside the formal school system and ranges from individualized apprenticeship to nation wide literacy. It may be vocational such as staff training centres in Nigeria designed to provide employment opportunities to young school leavers and for other employed persons or girls' vocational establishments in many African countries which train girls in vocational skills and prepare young women for marriage and business (p. 17).

This definition gives a catalogue of what out-of-school education can do: it covers training in literacy skills, apprenticeship, vocational skills and business, all of which prepare participants for employment. 


\section{Empowerment}

The term empowerment derives from the "root word" power. Thus to empower means to give authority to, to enable a person or group of persons gain power. According to Okpoko (2002), empowerment implies that the person or group of persons being empowered must have hitherto lacked authority by circumstances either by denial or default.

There are many avenues of empowering people or giving them the strength, knowledge or information to act. For example, through education and training, an erstwhile illiterate can be empowered to develop to the extent of getting employment. Again, awareness creation or consciousness arousal, which Paulo Freire termed "conscientization" can be used as instrument for empowerment. According to Freire (1978) conscientization is a process by which the poor become aware of themselves and their innate potentialities to restructure an oppressive society. Thus conscientization, to Freire was to provide the stimulus which would energize marginalized adults to effect a transformation in the conditions which were oppressing them. This is the theoretical thinking of this paper.

In this discuss, empowerment is taken to mean a process whereby the rural adults in Etche ethnic nationality are enabled (empowered so to say) through awareness creation using out-of-school education programmes to improve upon what they know before or undertake new activities in order to influence changes in their socio-economic, cultural and political environments.

\section{Community Development}

To put community development into proper perspective, the term "community" must be defined. A community is defined by Hillery (1955) and Jonassen, (1959) as a grouping of people within a geographical area, with a division of labour into specialized and interdependent functions, with a common culture and a social system which organizes their activities, whose members are conscious of their unity and of belonging to the community and who can act collectively in an organized manner.

The term development can be taken as a process of satisfying the basic needs of an individual and community and/or society. According to Obi (1987), development is an elusive and ambiguous term and no definition seems entirely satisfactory. It is a multi-dimensional problem which requires multi-disciplinary attack. Moreover, it has to do with all aspects of people's life - economic, social, political, legal, administrative, etc. To Fadahunsi (1986), development is the mobilization, adaptation and use of human and other resources within a state to meet the needs and possibly, the wants of the citizens of the state.

Community development therefore, means an educational process through which people determine their needs, set targets or objectives and make adequate plans on how to attain them (Nkememewa 1987). It seeks to help people not only to become effective and efficient in their involvement in solving community and personal problems but, also in seeing to their action priorities.

In this wise, the rural adults in Etche ethnic nationality who have been wallowing in illiteracy, poverty, hunger, complacency, unemployment etc. require to be woken up or stimulated to seek ways of improving their standards of living thereby contributing to the 
development of their communities. This paper explains how out-of-school education can be utilized to achieve this feat.

\section{Problems of Out-of-School Education in Nigeria}

In Nigeria, out-of-school education; call it non-formal education, is not entirely a new concept for as early as 1943, the colonial administration had published its white paper titled "Mass Education in African Societies". The policy defined goals to be pursued as:

(i) the improvement of the health and living conditions of the people;

(ii) the improvement of their well-being in the economic spheres;

(iii) the development of political institutions and political power until the day arrives when the people can become effectively self-governing.

Since 1943 many African countries have become self-governing and introduced some out-of-school outfits which operated mainly in urban areas with no impacts in rural areas. The Directorate for Social Mobilization (MANSER) 1987, is a typical example in the case of Nigeria. With the historical antecedent of out-of-school education in Nigeria, the expectation is that it ought to be firmly developed and integrated into the educational system by now. But it is still at the periphery - why?

One major problem of out-of-school education in both Nigeria and other countries as identified by Jegede (2005) is 'the competitive approach to formal education the protagonists of the concept portray it". An example of such assertion is stated by Coombs (1989) that many developing countries have become convinced that traditional primary schools are not the only or even the best way to provide their children and youth with the basic skills and knowledge they will need in life. In this regard, according to Jegede (2005) when out-of-school education is seen as a "better" alternative, or as a "solution" to the problems of formal education, the tendency is for the protagonists of formal education to try and defend it by becoming antagonistic to the progress of out-of-school education. This competition and bias against out-of-school education was reflected in the UBE Act of 2004 where no provision was made for the Nigerian National Council for Adult Education, nor for any of the Non-Governmental Organizations in out-of-school education in the membership of the Board of the UBE Commission. In fact, this exclusion has the tendency of neglecting the non-formal education sector to the detriment of the emancipation and transformation of the country.

Another problem of out-of-school education is lack of adequate organizational structure. For example, in Nigeria and elsewhere, formal education has its ministry (by whatever name) to watch over it and fight its battles so to say, but non-formal education (that motley assortment of out-of-school training and educational activities), has been everybody's business and therefore nobody's. This situation therefore calls for the establishment, the strengthening and the invigoration of a supplementary and/or complementary alternative option under its own ministry. Supporting this view, Coombs (1970) perceived a clear need to develop a better division of labour and better integration between formal and non-formal education and stop short changing out of school education. This measure will give out-of-school education a strong voice to speak on its own behalf on national, state and local levels.

The unwieldy number of personalities and programmes operating within the province of out-of-school education creates problems of their own. Experts in other fields such as health, 
agriculture, environmental education, the police, air force, army, judiciary, church, ministry of women affairs and local governments, etc. bring their backgrounds to bear on the practice of out-of-school education. Likewise, the programmes that conceptualize out-of-school education are becoming systematically ambiguous that its full meaning can only be better understood when the characterizations of the subsystem are expressed. The implication is that at federal, state and local government levels, apart from the seeming neglect or non-recognition of out-of-school education system, there is no dedicated commitment to fund out-of-school education in Nigeria (Akintayo and Oghenekohwo, 2004). Unless development partners are brought into the show, Nigerian governments alone cannot equitably shoulder the responsibility of funding out-of-school education programmes in the country.

\section{Roles of Out-of-School Education in Empowerment of Rural Adults in Etche Ethnic Nationality}

The Ghana Commonwealth Conference on Education in Rural Areas (1970), Thompson (1983), and Ihejirika (2007) identified the following categories of rural adults that can constitute beneficiaries of out-of-school education. They are:

- $\quad$ traditional farmers;

- $\quad$ primary/secondary school dropouts;

- $\quad$ large number of unemployed youths;

- $\quad$ the self-engaged in off-farm activities.

Coincidentally, in Etche ethnic nationality, a similar category of rural dwellers are prominent. In the nationality, every family head is a farmer and happens to be illiterate. This common phenomenon left two problems which out-of-school education can handle because those crop of adults are above formal school age. But for out-of-school education to succeed in helping them change their attitudes toward traditional and unprogressive subsistence framing they are used to, their illiteracy disease must be cured first as Thompson (1983) highlighted:

Illiteracy makes it difficult to teach new techniques, poverty prevents investment in new facilities, and a land tenure system which does not establish legal land boundaries and security of tenure deprives the farmer of an asset against which to raise loans and gives him no incentive to invest in long term improvements (p. 108).

To clear this first hurdle therefore, adult literacy education which emphasizes the teaching of the 3R's - Reading, Writing and Arithmetic or numeracy should serve as first course since literacy is both a necessary skill in itself and the foundation of other life skills. This can be effectively achieved among illiterate farmers in Etche ethnic nationality on the provision of Community Learning Centres (CLCs) at designated points by the two council chairmen in the nationality. Beyond this baseline education, the farmers are introduced to functional literacy which combines the skills of literacy with socio-economic activities. In this case, since the people have a common occupation, it becomes possible to integrate the terminologies or registers of their occupation into the literacy component of the programme. Then the desire and ability to read, write and compute materials in the vocation will motivate 
the farmers for better participation. Hence, Imhabekhai (2009) emphasized that the utility of the skills will definitely bring about functionality and progress in the farming occupation and fosters permanent literacy among the participants. Thus, literacy education for the unschooled, according to Thompson (1983), will facilitate a flow of vital ideas and information, increase their awareness of the situation in which they live, and of the possibilities and choices before them. Moreover, in our case, it will motivate illiterate farmers in Etche to increase their efforts to break out of poverty cycle as a result of the new vista of life which literacy will open for them. This will serve as empowerment for them.

The other challenge is the practice of an economy with local technology which translates to low productivity and poverty among farmers in Etche ethnic nationality. This age-long problem can successfully be met through agricultural extension education, which is a process through which innovations in both methods and techniques of production as well as new improvements in agriculture are brought to the knowledge of farmers through individual contacts with agricultural agents from Ministry of Agriculture, Agricultural Development Projects (ADPs) or from Agricultural Research Institutes in Nigeria. According to Williams (1981) agricultural extension education:

Is a voluntary out-of-school education programme. It employs teachings/learning principles that effect changes in the farmers, generally carried out in an atmosphere of mutual trust and respect between agricultural agents and their clientele. (p. 144)

Upon registration by farmers in Etche at the two Local Government Councils, relevant agents are sent from the headquarters to visit them according to schedule during which time, apart from teaching new techniques of cultivation, they are taught other processes involving development and supply of new improved seeds and seedlings, fertilizers and insecticides' applications, storage and marketing of products, often through specially created marketing boards. It is envisaged that through the services of experts and demonstrators to the farmers, there will be self-sufficiency in food production through introduction of varieties of non-formal vocational courses such as mushroom breed, chicken raising (poultry), fish pond, snail breeding, rabbitry etc. as against the practice of planting yam and cassava. Frankly speaking, the services of agricultural experts will help create a conducive frame of mind and attitude in Etche farmers for acceptance of change from the old ways of doing their things to the new including formation of cooperatives and credit societies as well as bank loan facilities and so on, all of which will revolutionize the erstwhile unprogressive socio-economic activities to a more functional economy and development.

The second category of rural dwellers that populate Etche ethnic nationality is formal school dropouts mostly from primary and secondary schools. They have no skills as to search for jobs even menial ones, neither can they enter institutions of higher learning because of lack of certification. They roam about, some doing motor-cycle transport business that cannot lead them to self sufficiency because they rent the motorbikes. In fact their learning needs can be conveniently handled by using remedial and later continuing education components of out-of-school education. Remedial education, as the name implies, is a form of adult and non-formal education which gives extended opportunities for learners to make up the 
inadequacies in their previous school experiences. It presupposes that the learners had earlier taken part in one type of educational programme but could not complete it due to certain unfavourable conditions. Since it is not feasible nor desirable to send them back to full-time schooling, the change must be effected through remedial part-time education to enable them re-inter formal education if need be, or opt for various vocational skills training for self-sufficiency or employment. Additionally, as the case may be in a rural environment like Etche, programmes that can generate community development spirit e.g youth clubs, scouting, women organizations, young farmers clubs, etc. are relevant to give those early dropouts some sense of responsibility and patriotism.

Another identified subgroup of beneficiaries of out-of-school education in Etche ethnic nationality are the unemployed youths. Lack of relevant skills to labour demands is a major reason for not securing job at all. Those among them who are illiterate need to go back to basis for basic literacy training to enable them pick up from there on a stronger footing as to be empowered in economic activities which will improve their productivity and thus contribute to community development.

The literate and jobless among them require those basic skills that are not transmitted through formal schooling. They require - life skills which include technical and manual skills that are required to secure gainful employment, skills of the kind that enable people to feed their families, to keep them healthy, and to protect them from illness. In the case of jobless youths in rural Etche communities, vocational skills training in weaving of cloth, shopping and school bags, crafts production such as pottery, knitting, sewing, tie, and dye, bricklaying, block molding, house-roofing, pest-control, cassava processing, baking, candles, soap and pomade, etc. are indicated. The skills if well acquired, can enable a youth improve his lifestyle by earning income from his small-scale business. It is not in doubt that where proficiency is demonstrated, the acquired skill could lead to securing job or becoming self-employed.

Lastly there are a good number of identified youths in Etche ethnic nationality who are engaged in off-farm activities such as carpenters, drivers, local gin distillers, retail (petty) traders, hair dressers, etc. in order to eke out their living. All of them require retraining to up-date their technical know-how and operate at an acceptable standard within the ambit of government regulations. Their retraining could be under short-term workshops or apprenticeship courses since adults would need less time-consuming experience instead of pro-longed programmes. The anticipated training and retraining short courses are aimed at enabling the participants become more capable of doing the jobs they are doing at present or to do new kinds of jobs.

In this analysis, it is clear that out-of-school education and training programmes have all it takes to empower the various categories of rural adults in Etche ethnic nationality after which they become instrumental factors for community development of the nationality.

\section{Conclusion}

This paper has ex-rayed the concepts of empowerment and community development as they relate to out-of school education. Similarly the relevance of utilizing out-of-school education to empower different segments of rural adults in Etche ethnic nationality was examined as well. Rural adults in the nationality were all along subjected to formal education 
system that paid insignificant attention to out-of-school education with the result that acquisition of relevant life and vocational skills which are prerequisites for occupation eluded most segments of people in Etche ethnic nationality. For the rural adults in the nationality to have both theoretical and practical knowledge, the monopoly of formal education in the area needs to be broken up by recognizing the practical utility which out-of-school education provides to the participants. It is capable of bridging the gap created by the limitations of formal education; be it in the areas of improved agricultural productivity, skills acquisition, vocational education, employment, health, on-the-job training, literacy and functional education, etc. and where necessary, out-of-school education provides additional route to career progression or for re-entry of dropouts into formal education sector. Therefore, the role of out-of-school education in empowering various segments of rural adults in Etche ethnic nationality with relevant life-giving/vocational skills is established.

\section{Recommendations}

Gleaning from the discussion of this presentation, the following recommendations are proffered for consideration.

1. There is need for institutionalization of Non-Formal Education out-of-school education under a separate Ministry of Non-formal Education to oversee the activities and programmes of out-of-school education.

2. The tendency of governments to place more emphasis on formal education system and leave out-of-school education at the periphery, and the urge to concentrate development plans in urban areas at the neglect of rural areas should be drastically reversed to make for even development of Nigeria.

3. Local Government Councils, Etche and Omuma inclusive, should consider development of rural areas their priority and establish out-of-school education development schemes such as local technology workshops, cottage and small-scale industries, skills acquisition/vocational centres, crafts development centres, international communication technology centres, etc. to provide employment and training for rural dwellers.

4. The curriculum of the Universal basic Education (UBE) programme in Nigeria should be diversified and implemented including pre-vocational technical and skills acquisition courses to empower school-leavers with various occupational skills.

5. Out-of-school education should therefore become a national programme whereby people in their communities are empowered and supported to put into teachable units of all kinds of daily-life activities, special interests and problem-solving situations of all the social classes in their different work locations, family environments and social conditions. 


\section{References}

Amirize, B. (2003). Adult and Community Education: Policy and Design. Owerri: Springfield.

Bown, L. and Okedara, J. T. (1981) (Eds). An introduction to the Study of Adult Education: A Multi-Disciplinary and Cross Cultural Approach for Developing Countries. Ibadan: University Press Ltd.

Coombs, P.H. (1970). The Need for a New Strategy of Educational Development. In R. Symond (ed) Internal Targets for Development. New York: Harper Colophon Books, $143-144$

Evans, D. R. (1981). The Planning of Non-Formal Education. Paris: UNESCO Institute of Education Planning.

Fadahunsi; (1986) cited in E.I. Itanyi, Archeology and Community Development in Africa. Journal of Education and Development, Department of Adult Education and Extramural studies, UNN 1, (I), 73-80.

Federal Republic of Nigeria (2004). National Policy on Education, Yaba, Lagos: NERDC Press.

Freire, P. (1978). Pedagogy in Process: The Letters to Guinea-Bissau. New York: Sebury Press.

Hillery, G.A. (1955). Definitions of Community: Areas of Agreement. New York: Rural Sociology (20), 111-123.

Ihejirika, J.C. (2007). Fundamentals of Adult Education and Community Development. Uyo: Abigab Associates.

Ihejirika, J.C. (2003). A Handbook on Distance Education (New Edition). Port Harcourt: Sons Communications.

Imhabekhai, C.I. (2009). Programme Development and Management in Adult and Non-Formal Education (Rev. Ed). Ikota Isolo: AMFITOP Books.

Jegede, S. (2005). The Compulsory, Free, Universal Basic Education Act of 2004: The need for NNCAE to Act. In Adult and non-Formal Education in Nigeria: Emerging Issues. Paper from the NNCAE Annual conference, Ibadan, Nigeria, November, 27-December $1,169-180$. 
Jonassen, C.T. (1959). Community Typology. In M. B. Sussman (Ed) Community Structure and Analysis. New York: Thomas Y. Crowell Company.

Nkememewa, S.S. (1987). Problems of Community Development in Ihembosi (Ihiala L.G.A. in Anambra State). An Unpublished B.Ed. Project. UNN.

Oghenekohwo, J.E. (2005), Economic Returns of Non-Formal Education Investment and the Budgetary Dilemma for Sustainable Development in Nigeria. Paper from the NNCAE Conference, Ibadan, Nigeria. Nov. 27-Dec. 1, 58-71.

University of Ghana Conference on Education in Rural Area. Final Report of Workshop on Out-of-School Education and Training Young People. 21 March - 2 April, (1970), 1-48. 